\title{
"Little Englander" - Fawlty Towers A Textual Analysis of Nationalistic Ideology
}

\author{
MATTHEW BARTLEY, University of Sunderland
}

\begin{abstract}
It is often agreed upon that television texts have provided an image of 'Britishness' that constructs an image of the nation state. This in turn leads to the representation of community in British sitcoms where one example is Fawlty Towers. Here we have a small community as a mini-construction of Britain complete with its 'strengths' and 'traditions'. This paper then, will elaborate through the analysis of narrative developments, thematic concerns and visual and linguistic analysis of the characters, just how Fawlty Towers showed this notion put into practice.
\end{abstract}

Considering what is considered the essence of 'Britain' in a textual example of a sitcom, it investigates how this ideological notion is applied within the textual narrative. This includes which characters are deemed worthy of inclusion in this mini-Britain, and which are not, and which ideological beliefs inform the notion of 'Britishness'.

\section{KEYWORDS}

Textual analysis, thematic, narrative, visuals.

Research has shown that when studying communities, one aspect that is of paramount importance to their formation is that of difference, or rather the acceptance of difference (Bauman, 2004; Lacey, 1998; Pickering, 2001; Tueth, 2000; and Tyler, 2005). Historically, communities have been formed around workplaces, uniting its denizens under a common banner despite the fact that their chosen occupation may be the only thing that the communal inhabitants share with each other. Difference is not anathema to the conception and construction of a community as long as the difference is integrated into the structure of the community. This acceptance of difference is what leads to the mostly harmonious communal life that is often regarded as the essential form of community. However, when difference is not accepted into the communal structure, conflict, clash and a failed community are the inevitable consequence.

The differences in community are a major underpinning of their representation within various television genres, from drama to documentary to sitcom. Sitcoms in particular use the differences that exist in community and more often than not posit a situation where the difference has not been accepted and derive their comic effect from the clash and conflict that is instigated. The vast majority of these conflicts and the comedic situations that sitcoms 
revolve around, are based upon the class structure and hierarchies that evolve out of and exist within the communal structure. From Hancock's Half-Hour to Steptoe and Son and Only Fools and Horses, the class system, and how it positions characters in the narrative within society and community, has been a constant source of vexation for the characters and a mine of drama and interest for the writers, particularly when tackling the notion that it is a site of conflict (Chambers and Prior, 1987; Hartley, 1999; Innes, 1992; and Wagg, 1998). However, another aspect of community and difference that has a particular impact upon how they are formed around a "them against us" ideology is the notion of nationalism, national identity and the idea of nationhood. Nationality, and pride of it, is often loosely referred to as a virtuous quality, yet it is a quality that has its roots in selective choosing of what constitutes the 'nation', and leaves out as many people as many people as it includes. National identity and nationalism revolves around the idea that certain symbols or figures are what are imagined to be what constitutes the nation (Bilig, 1995; Anderson, 1983), existing as easily identifiable of what it means to be British for example, rather than producing a concrete piece of evidence that proves the values and traditions of Britain. However, these values can never be agreed upon by all members that dwell within the geographical boundaries of the community, as not all of them share the same characteristics that a national identity presupposes. For all those that state the 1970s were the 'good old days' when you could leave your back door open, there are just as many who will verify that you could not, or who were not made to feel welcome in Britain because of factors such as their ethnicity, sexuality or class position. In short, the agreed version of what constitutes the national identity rests in the hands of the majority and the elite who have the greater power in the country. It is therefore their version of national identity that becomes the widely held one, complete with their choice of values, historically important dates, sites, figures, heroes and villains (Smith, 1991).

Nationality then is as much a political and social process as it is a historical and geographical one, ensuring that there is one 'truth' about the nation that is widely held to serve the interest of those in power and constantly establishing difference within the country as well as similarity and solidarity (McCrone, 1996; Thompson, 1995). It therefore establishes the idea of a homeland that will forever belong to those that identify and agree with the values that it presupposes as right, correct and of great value, forming an emotional attachment (Anderson, 1983) with the idea of it, and fighting against anything that threatens it. The national identity then is seen as something inherently belonging to those born within the geographical borders of the country and not something that can be assumed or picked up by outsiders (Higson:1998), as they are not party to the distinctive features of the nationhood, whatever they may be. It goes beyond mere physical appearance - after all, what physically separates a Dutchman from an Englishman for instance? - but to something more abstract. In short, the national identity is something imagined and constituted through use of social and political processes of power (Jacobsen, 1997). If the construction of a national identity is something that is constructed on a grand scale, then it is a mechanism that is often repeated on a smaller, local scale within the community.

This leads us onto the example of Fawlty Towers. Fawlty Towers is a sitcom produced in Britain in the 1970s. Written by John Cleese of Monty Python fame and his then wife, Connie Booth, it revolves around a hotel in the seaside holiday resort of Torquay. Cleese plays the hotel owner, Basil Fawlty, who owns and runs the hotel alongside his wife, Sybil. Also helping them to run the hotel is the maid Polly and the Spanish waiter Manuel. Basil has grand dreams of his hotel, that one day it will become a place exclusively for the titled and privileged in society, a social circle that he believes he should be a member of. However, the 
reality of his hotel is that it is a place where anyone can come and stay. This means that Basil, an argumentative and dictatorial snob has to put up with people of different ethnicities (other than English) and the working class coming to stay in his hotel. This infuriates Basil, who barely contains his loathing at such people in his hotel, and leads to the conflict and chaos that constantly bedevils the hotel. In terms of community it is an example of a small, closeted community, where the narrative rarely takes place in the outside world. Instead, the majority of the action takes place within the walls of the titular hotel, and we see that this is a community dominated by its leader, Basil Fawlty. However, this is a community that is not founded on the acceptance of difference. Instead, the character of Basil has a very narrow view of just which characters should be allowed to stay in his hotel and his attitude towards the various guests differs because of this, leading to the many comic situations that have helped to constitute Fawlty Towers as one of Britain's greatest sitcoms. The differences that threaten the security and communality of the hotel are not those of a hugely distinguishable nature, but are instead more of a personal idiosyncratic idiom from Basil. He does not approve of guests that engage in what he believes to be immoral behaviour, for example unmarried couples sleeping together or guests that get loudly drunk, and cannot accept the fact that there are those who do not share his opinions and what he would see as his moral fortitude. This points towards a bigger concept and driving force behind Basil's ideology, which is that of a nationalistic fervour. Throughout the series, his character constantly refers to Britain and England (as we shall see, the two are easily interchangeable for Basil) in glowing, patriotic terms, as a nation of immense value and fortitude. For the character of Basil, everything good, strong or notable in a person is related to their 'Britishness' or 'Englishness'. Ergo, anything irritating, shameful or dislikeable (by Basil's standards) in a person is an affront to Basil's nationalistic pride and is revealing of how far away from the concept of being truly English or British they really are. This nationalistic ideology behind Basil makes itself known in several ways as we shall see. Firstly, there is Basil's constant references to famous people, historical figures and important dates that he believes are intrinsically important to the history, traditions and values of the 'true' Britain/England; his attitude to anyone of another ethnicity besides British/English; and his attitude to anyone who is either working class (a negative concept in Basil's eyes) or middle class and upwards (a positive concept in Basil's eyes). It is because of these nationalistic attitudes and ideology that the hotel is a community that is perpetually wracked by conflict and on the point of chaos.

Basil's insistence on nationalistic pride is a concept used within the narrative to accentuate the type of people that he has staying within the hotel. The hotel is seen as a physical environment that is an extension of the character (Barber, 2002 and Billingham, 2003), in this case Basil himself, as it is named after his own name and comes therefore endowed with all the values and traditions that he holds dear. It is also a physical construction of tiers and levels that further represents the type of tiered society that Basil believes in. Whilst Basil is forced to allocate the rooms to anyone who has the money to pay for them regardless of class, it is notable that all the work in the hotel happens on the very lower level whilst those who are privileged enough to be waited on are elevated to the floors above. As noted one such set of values that he does hold dear is that of the privileged and titled class system that his character believes to be an essential component of England. We can see how important this is to his character in the first episode, A Touch of Class. Here, Basil is excited by the arrival of a titled guest, Lord Melberry, who has unexpectedly arrived to stay for a number of nights. Basil is sent into a mania by the fact that his hotel has finally started to attract a higher class of clientele and proceeds to rearrange the workings of the hotel around Lord Melberry. Other guests are moved from the best table in the restaurant mid-meal to make way for him, 
Basil fawns around him and does everything in his power to accommodate all his wishes. However, Melberry turns out to be a fraud and has conned Basil out of a large amount of money. The episode ends on a horribly ironic note for Basil as his rage at Melberry frightens away a genuine Lord and Lady who have arrived to stay at the hotel.

It is apparent right throughout this episode that Basil has an obsession with the class system and whom he deems worthy of being in his self constructed community. He already has one titled permanent resident in the hotel, Major Gowen, and his attitude towards him is mainly one of friendliness and relaxed conversation. This is in complete contrast to his attitude towards the paper boy who has a cheery working class accent or another guest, Mr Brown, who greets Basil with the greeting 'Allo! Got a room?' that makes Basil flinch away from him, as if being assaulted because of his casual use of the English language. His attitude towards these characters is of barely disguised rudeness, simply because they are codified within the text as working class characters who do not speak in the mannerisms that characters such as the Major, Melberry or Basil himself do. This is a concerted and concentrated effort by Basil to create a community that revolves around a nationalistic boundary that is aided in its creation by setting up criteria for entry that act as boundaries for access into the community. Basil's pride in his nation is tied to a mythological belief in the old British empire. In his contemporary Britain he firmly believes that the working class should know their place in society. His is a character that believes there is a particular place for everyone in society which should not be questioned and everyone should be treated accordingly to this place.

The working class are not deserving of Basil's attention and we see this in a conversation Basil has with another guest. As ever, the conversation revolves around the working class and the industrial strikes that were currently blighting Britain. Muttering about 'another car strike', he then rips into 'layabouts on conveyor belts, stuffing themselves with my money'. It is noticeable that Basil takes this action by another (lower) class as a personal attack on him - a notion that belongs to the middle class who, if isolated from community which Basil is in terms of who we wishes to be in his community, have a neurotic belief that society is hostile towards them (Nisbet, 1953), once more showing how he views the class structure of Britain, which, as we have seen, is something that he wishes his hotel to be built around. It is an attitude that shows why the character of Basil Fawlty is an unsuitable community leader and why his community does flounder. Part of the notion of community revolves around a fraternal obligation between its members that everyone should endeavour to make communal life as comfortable as possible for everyone else. This is clearly a system that Basil would have little time for. As that sample of dialogue shows, he sees the working class as a group that leech off his hard eared money, something that he highly resents. Basil is not a character that believes in the notion of fraternal obligation. He disparagingly refers to the car strikes as socialism once more, and states that if 'they' ('they' being the working class) are dissatisfied, 'they should get another job building cathedrals or writing concertos'. It is clear then, from these activities that Basil mentions, just what kind of people and occupations he sees fit to stand alongside him as an Englishman. For Basil, a task such as building a cathedral or writing a concerto is something noble and privileged and more worthwhile than working in the industrial sector. However, it is seemingly lost on Basil that the tasks he mentions would bring very little money into the economy and would actually take far longer to complete than the industrial action he bitterly complains about. Instead, he would much prefer for that time to be spent on something that has a great deal more visual and symbolic merit. It can be seen then, that Basil's view of how life - specifically 'English' life - should be, greatly informs how he runs his hotel and how he tries to structure his community. This is a notion that is 
perhaps partly influenced (or if not directly influenced, can certainly be linked alongside, particularly in terms of era and historical cultural development) a literary development of the 1970s where a thematic genre of play sprang up, loosely termed 'England-in-decline' plays (Chambers and Prior, 1987). These plays were an investigation into how the people of England dealt with the fact that England had lost its prestige as a world empire, and the inevitable moral scrutiny that followed. This theme is certainly one that has roots throughout Fawlty Towers as Basil clearly believes that England, with its industrial car strikes and working classes able to afford holidays in his hotel, is certainly in decline. This perhaps is one of the driving motivations behind Basil's character: trying to reassert or recover or rebuild in his community an England that has been lost, perhaps forever.

If Basil then believes in a firmly structured and firmly tiered class system, it is a system that is rooted in a historical tradition and more specifically a remembrance or nostalgic longing for the old British Empire. Basil's view of how his community should be constituted and how it should represent Britain is based around something almost mythological, almost intangible. $\mathrm{He}$ is extremely proud of his antique coin collection and says admiringly, 'the old British Empire', when showing them off to Melberry, and the coin collection function as symbols of how Basil believes a community in England should function. They have little value in society apart from being symbolic pointers of the British Empire that Basil still strongly believes in (Cohen, 1985; Barthes, 1993). This points towards the traditions and values that inform Basil, and therefore what informs the community he tries to construct which is that of the old imperial world based around social deference, class stratification and the unquestioning acceptance of it. This character detail relates to a study of films set within New York where the idea is outlined that the city (which can be seen as a communal place), can function as a historically defined place that therefore places the characters within in the place where they should be - which for Basil would be the working class guests 'knowing their place' (Shiel, 2003). Basil's pride and national identity can be seen as both positive and a right (Pickering, 2001) and is formed through the use of symbols which are intrinsic to the nation and its soil. This notion can also be developed alongside the example of the various iconic structures of New York serving as examples of modern man's dominance over life and his accomplishments. This ties neatly into Basil's character as his pride in these symbols, do represent just how the British Empire did try and dominate the age in which it was at the height of its powers. This critical development also ties into the fact that colonialism (a period of history Basil's character surely feels pride in) is established through military violence (hence Basil's constant referencing of old war dates, places and characters), but is sustained through cultural means (Pettitt, 2000). If the hotel is Basil's 'colony' then, he tries to sustain the British superiority in it, by his insistent enforcement of his rules and standards. Basil's character clearly believes that a national identity revolves around a shared cultural history - for Basil this is an imperialistic history and also an 'imagined community' as it moves away from social affiliation to something that is based more upon mythological symbols and values (Pickering, 2001). These symbols can be seen in Basil's proud collection of coins and his constant referencing to dates and names that reek of the old British Empire (when he feigns ignorance of his wedding anniversary in a later episode he asks if the importance of the date is Agincourt, and is clearly an admirer of people like Gladstone or Earl Hague). Basil's definitions of what makes Britain and therefore his ideal of community are aspects and objects, which have no value other than on a purely symbolic level (Cohen, 1985). Likewise, his habit of often referring to old mythological or wartime figures and dates to make a point of them being an example of the 'correct' way of doing things and running society. They have no real, meaningful impact or use beyond that of the symbolic. It is therefore the case that whenever Basil feels that his ideal of community being threatened, it is 
being threatened on a symbolic level which can range from the cockney working class guest such as Mr. Brown staying in his hotel, thus immediately lowering the tone of the hotel, and in a wider aspect Britain, through Basil's character's eyes, to the arrival of a Mr. Johnson who in an episode entitled The Psychiatrists draped several different ethnic and cultural symbols around his neck and made jokes about Margaret Thatcher. This reliance on symbols of the British empire thus acts as a marker to show how much of his ideology and process of community construction relies upon separation and defining boundaries between himself and those that are different to him.

Perhaps the biggest pointer of Basil's support, and love for the old-world values that he believes represent what Britain or England is the episode entitled Waldorf Salad where Basil has a conflict with an American guest. Here, Basil takes umbrage at the description of the M5 as a little back street and defends 'the damp, the drizzle, the fog' as Sybil describes it, as 'bracing' and 'the English Riveria'. This demonstrates then, just how defensive Basil is about the traditions that he feels epitomises England, and therefore his hotel. However, Basil is too close-minded to entertain the thought that some people may not agree with him, and this intractability is reflected in the way that he controls the hotel. People are not made welcome if he feels that they do meet his standards, and cultural differences are not accepted - unless they are being paid for, which they are in this case. It is this stubbornness and unwillingness to bend the rules of the community that causes it to be so oppressive and unwelcoming to people. This leads to an angry confrontation at the climax of the episode where Mr. Hamilton unleashes a tirade about how 'this crumpy dump' is the worst hotel in Europe, to which Basil defends his community in nationalistic terms: "we value things in Britain that America has forgotten' and the Major backs him up by citing a place (another community) in Eastbourne that is worse. This community then, is not just a place to stay for guests, or an avenue of money for Basil, it is an extension of England, and one where Basil feels that his community of fellow Englishmen will pull behind him to confront the 'invading' American. However, Basil is sadly mistaken, and instead his community take this opportunity to complain to him. However, Basil takes this in typical fashion, and his view of a solid community around is shattered, in a rant that bears full repeat here:

You ponce in here expecting to be waited on hand and foot, while I'm trying to run a hotel here. Have you any idea of how much there is to do? Do you ever think of that? Of course not, you're all too busy sticking your noses into every corner, poking around for things to complain about, aren't you? Well let me tell you something - this is exactly how Nazi Germany started. A lot of layabouts with nothing better to do than to cause trouble. Well I've had fifteen years of pandering to the likes of you, and I've had enough. I've had it. Come on, pack your bags and get out.

It is interesting to note that, after having previously relied on this community as being 'one' and being together, Basil criticises them as 'you people', illustrating that he clearly sees himself as someone different, and better, than the people he feels he is forced together with. This is a sequence of narrative events and a narrative theme in general that can be linked back to a theatrical tradition whereby writers after the second world war would try and produce plays that showed Britain as one united nation and not one that was divided along class lines (Chambers and Prior,1987). However, the reality they found within the plays was that this was a pipe dream, and the notion of class was often key to understanding Britain's past. This is crucial to a reading of Fawlty Towers then and an understanding of the character of Basil, as Fawlty Towers shows that Basil's community (and therefore, in Basil's eyes, Britain) is clearly defined along class lines, which is an aspect Basil certainly relates to 
Britain's past. For characters such as Sybil, Polly and the majority of the guests, the understanding that the community is built along class lines, is of very little importance to them. It is much more of utilitarian point of view that these characters share, in that they view the hotel as a place where the classes can co-exist peacefully, where the working class are waited upon by the middle class - but for a price. However, the character of Basil is unable or unwilling to exist this co-existence, no matter how short lived it is, and as shown previously instead views the co-existence as one of a war of attrition between the classes to restore the rightful order which Basil ties as far back as Britain's feudal past (St. George and the Dragon is another mythological symbol that Basil talks about proudly). These are themes found in literary tradition including such playwrights as David Mercer who believed that Britain was irretrievably class-ridden and Howard Brenton who detailed concepts of Englishness through his works (Chambers and Prior, 1987), and it should be noted again that Basil switches between descriptions of 'Britain' and 'England' quite often. It is more often the case that when he refers to Britain it is as a unified nation or common identity. When he refers to England however, it is more about highlighting just what aspects make Britain so great - inevitably these aspects are the English ones).

If the character of Basil has a concept of nationalism that revolves around the notion that Britain is at its strongest when it is following the historical tradition of the class system and its roots to the old British empire that he values dearly, it follows that this will impinge on Basil's attitude to those that are not British or English. This, like his attitude to any other working class characters or guests, is one of rudeness and of the belief that any other nationality is secondary or lesser to an Englishman.

In one episode Basil is complaining about car strikes yet again and baldly states, 'whatever happened to doing something for your fellow man?'. This utilitarianism however, is something that is clearly not part of Basil's character make-up. He does nothing for his 'fellow man' if he feels that they are below him and treats Polly and Manuel as the servants that he clearly feels they are. Manuel comes in for a double amount of Basil's disdain as he is not only part of the serving-class in Fawlty Towers, but he is also a foreigner. Basil's dislike for anyone not of British heritage is plain to see and he views Manuel not as someone who may learn something from him but as a hindrance, someone who does not belong but is useful because he is cheap and thusly reiterating the values that were prevalent throughout the old British empire that Basil values highly complete with military dominance and subjugation. This attitude continues in the episode Gourmet Night where Basil enlists Kurt, a Greek chef to make a menu for him although he initially does not know that Kurt is a homosexual who has a crush on Manuel. Even though he is preparing the gourmet food for him, Kurt is still disparaged by Basil. First of all, Basil assumes he is French, which shows his ignorance and how little time he has for anyone of another ethnicity. Later, when Kurt's problems become clear regarding Manuel, Basil makes a comment about Kurt's sexuality, as he claims, that, 'they invented it'. His ignorance is plain here from both the use of 'they' and 'it'. It is clear just how narrow Basil's standard is for those who should be members of his community, as Kurt is obviously doubly undesirable here as he is a foreigner and a homosexual. Even though Kurt's skill as a chef is plain to see, this does not mark him out as acceptable for Basil as anything other than a worker, again relating how the British Empire would treat different ethnic races, a process Basil is attempting to replicate here within his own community.

The obvious example of how Basil's character reflects the nationalistic values of another era is most clearly shown in his treatment of the Spanish waiter, Manuel. His character points 
towards a wider motif, which is that often chaos reigns in Fawlty Towers when someone from a different ethnicity arrives in the hotel, simply because Basil is so opposed to the idea of other nationalities being equal to his British/English nationalism. This can be seen in several different episodes with the various arrivals of Irish builders and German, French, Australian and American guests throughout the programme. Manuel also functions as a process by which Basil can finally demonstrate some power over another character. The language problems that Basil has with Manuel are symptomatic of the divisions within the hotel. Basil has made no attempt at helping Manuel fit in - at one point berating his Spanish as 'pidgin' while claiming that he knows classical Spanish - and instead lets this division within his community fester and spread. This leads to a constant state of confusion that could be avoided if Basil made any attempt to bridge the rifts within his community, instead of insisting that everything and everyone fits within his narrow structure of how things should be. It reaches a climax in The Germans when Basil fails to understand that Manuel is trying to tell him that there is a (real) fire in the kitchen during a fire drill. Therefore, because Basil has failed to fix the metaphorical rifts within the community, the community is almost literally destroyed. Even during this situation he displays no care at all for the people living within his community. Because they do not fit into his rigid order of how things should be, and presumably because they are of a class or nationality not good enough for him, he has little sympathy for them during the fire drill. 'I don't know why we bother, we should let you all burn!' he snaps at them at one point.

Basil's mission of upholding the values and beliefs of the old British empire can be seen, as well as in his treatment of Manuel, in his comment in a phone call to the Irish builder O' Reilly in which he makes an insulting reference to the potato famine before telling him to simply go away when Melberry arrives and then hanging up on him. These are all aspects of Basil's character that are developed and repeated throughout the series and affect just how the community here is represented, such as when the visiting German guests irritate him to the point where he growls at them, 'who won the bloody war anyway?', thereby showing just where he thinks the Germans should be in his communal ranking. Basil's view of nationalism then and specifically how it relates to other nationalities is almost always related to warfare or conflict as well as being related to an old era of British dominance and power. It is not surprising therefore that his attitude towards these different nationalities, and more importantly how Britain is therefore superior in every way to any other, is the aspect that causes conflict and chaos within the hotel. This is further seen in an episode entitled The Wedding Party where Basil throws a group of guests out after mistakenly believing that they are all involved in extramarital affairs. When Sybil tells him the truth of the situation and instructs him to apologise and own up to his mistake, his hysterical reaction is: 'is that what made Britain great? I'm so sorry I made a mistake!'. There is no clearer an indication of Basil's nationalistic pride than here. To be British is to be a great and superior nation, to be British is to be of a certain moral standard (i.e. no sex outside of marriage), and to be British is to not own up to any mistakes.

In The Psychiatrists a great deal is revealed of just who Basil feels is fit to be part of his community and who is not and how this relates to his strong nationalism. The episode revolves around a number of different guests that all check in at the same time. Firstly there is Mr Johnson, a young, working class heavily sexualised man who Sybil is clearly attracted to. Secondly there are the Abbots, a pair of married psychiatrists, and lastly there is a young Australian woman who Basil is also attracted to. Basil's values are clearly seen in his differing attitudes towards Mr. Johnson and the Abbott's. As he notes to Sybil, they have 'both ends of the evolutionary scale in this week'. He also refers to Johnson as a monkey, 
and disparages the phallic and mythological symbols that he has hanging around his neck. $\mathrm{Mr}$ Johnson acts as a symbol of everything that an Englishman should not be, according to Basil. This is shown when Mr. Johnson asks if there is anywhere that serves French food, Basil flippantly says 'France, I believe', showing that the further away from his community Mr. Johnson is the better and crucially, somewhere foreign. For Basil, Mr. Johnson is clearly not what an Englishman should be about. This is further shown when Mr. Johnson makes jokes about what would constitute a list of the world's shortest books, which he believes would include 'The Wit of Margaret Thatcher' and 'Great English Lovers'. These jokes leave Basil visibly twitching in anger behind the desk, as Mr. Johnson is clearly attacking values and attitudes that Basil holds dear and believes should be reflected in his community. The portrayal of Mr. Johnson's character here as a counter culture figure (signified by the astrological and ethnic symbols he has dangling from his neck), acts as a complete contrast to everything that Basil's character embodies. Mr. Johnson is portrayed as a sexualised and very practical character, which certainly makes him a threat to the character of Basil and his values - thus making Basil, and not the counter culture character, a farcical figure. With his constant complaints about industrial strikes and obsession with the old traditions of the British empire it is clear that Basil is a conservative, and thus believes that his community should be aspiring to those values, and he will therefore not take any attacks upon them.

When Sybil makes the point about war medals being fine for a man to wear, Basil notes that Mr. Johnson must be 'the bravest orang-utan in Britain'. However, this is a very perceptive point made by Sybil, as she mentions people like Gladstone, Earl Hague and Baden-Powell, who were equally laden with war medals. This points out then, how Basil views people and the criteria that people should be judged on. People such as Gladstone and Baden-Powell should not be criticised for wearing medals, because they are wearing medals that represent the old British Empire, which, as noted before is something that Basil evidently aspires too. They represent the type of class that Basil looks up to, and the type of class that he feels should constitute the community that he is trying to build in his hotel. Mr. Johnson, is evidently not of this class, and it is quite telling that his medals which Basil dismisses so readily, are all of other cultures and ethnicities - in other words, symbols of people who Basil does not want staying under his roof. Any ethnicity other then English is something that is again mocked as Manuel is lambasted with the insult: 'a continental cretin....God knows what how they got an armada together'. This statement again shows how a lot of Basil's ideology goes back to the time when Britain was the dominant world force, and how the traditions he tries to implement in his hotel come from this time period. Later, Basil attacks Manuel as he gets him into trouble with Sybil, but is caught by Mr. Abbott. Basil pretends that he is actually teaching Manuel self-defence, with the aside 'Now that's how an Englishman would do it. Now a German would...', before aiming a kick at Manuel's unprotected stomach. Once again, we see how any ethnicity for Basil is 'lower' than the English - it is notable that the first excuse that Basil can think of in this situation is to pretend that he is imitating another nationality complete with behaviour that is not sporting or just and that traditional English beliefs are how this community should function. Basil's character relies on stereotypes of foreigners and other ethnicities (they do not fight fairly in this case) to cement his relationship of power over Manuel and other visiting ethnicities. It should also be noted that this community, with its emphasis on 'traditional' values and ethics from an older, imperial age, serves as a refuge for people like the Major and his use of language such as 'niggers' and 'wogs'. This is also reflected in the episode The Kipper and the Corpse via the woman with the biting dog, who insults Manuel for not knowing how to approach it correctly: 'Don't you have dogs in Calcutta?', she says, not attempting to find out Manuel's ethnicity, instead labelling him with the first nationality that comes to mind - and she clearly 
means it as a sly insult. With people like this (her accent strongly suggests someone from a privileged or upper class background), there is implicit criticism of Basil here, and the community he is trying to build, and the values that act as the bedrock for this community. If these are the kinds of people that Basil wants to solely base his community around, then it is a community of no real moral ground, based instead around outdated ideas of elitism and privilege. It is these factors then, combined with Basil's lack of real leadership skills that combine to make Fawlty Towers such an unsteady example of an enclosed community.

Throughout the series we see the character of Basil time and again refer to what he believes constitutes an Englishman or what it means to be British. For Basil this is something of character, of fortitude and something to be admired - but crucially it is something that is also nostalgic and of another time completely. He clings to the class structure of titles and privilege despite the fact that it is a changing structure that increasingly leaves Basil looking old fashioned and out of time because of his insistence on moral behaviour such as no sex before marriage and separate rooms for unmarried couples. Furthermore, this insistence upon these values leads to Basil taking a very strong attitude to those who do not agree with his principles. For Basil, the working class should know their place, keep out of his hotel and not complain about their place in life. Industrial strikes in particular are symptoms of unacceptable behaviour from a working class that has forgotten where their true place in society - one of uncomplaining servitude - lies.

However it is a twofold nationalistic attitude that Basil has. With his constant referencing of military battles, dates and figures, Basil is still in thrall to the notion that Britain is a strong, dominating military nation and this is at the root of his attitude towards other ethnicities. With his rude, belligerent behaviour towards them it is clear that he still believes that an Englishman should have dominance over any other nationality. However, what is seemingly lost on Basil is that his behaviour is influenced by the old British Empire. The attitudes that he embodies belong to a time that is gone and the figures that he values so highly are now of a nostalgic and almost mythological nature, tying in with the thought that community itself is an exercise in nostalgia (Delanty, 2005). His nationalistic ideology is fierce and committed but it is also one that has no place in the time of society in which he currently dwells. The social make up of society has changed as it is wont to do (Hoggart, 2004), like the world order, and they are changes that Basil has seemingly deliberately ignored. His nationalistic battle to uphold the values that he holds so dear is one that he views as crucial to the state of the nation, but within the context of the narrative seems a pointless clinging to old worthless symbols.

It is because of this central conflict within the narrative - Basil's values being eroded against his attempt to uphold them - that the hotel is perpetually beset by conflict and chaos, with the conflict being based in a nationalistic context, whether it be the nationalism values of what makes Britain great according to Basil, or the nationalism of England against another nation or ethnicity. The community is almost permanently fractured as the character of Basil is always erecting figurative and mental barriers between himself, who he believes is acting in the interest of and is a representative of the privileged and middle class, and the working class and other minorities (i.e. anyone who is not of the middle class, or is not white and English) who are unwelcome members in his own community. These barriers, amongst other acts of behaviour, are such things as refusing to listen to complaints or suggestions for improvement, inability or refusal to take onboard ethnic differences by learning other languages or letting the guests behave as they (reasonably) wish to. Resulting from the behaviour of Basil's character, which is a mixture of overly offensive and defensive 
behaviour, there is a constant conflict between the various and disparate members of the community with no hope of reconciliation or peace. At one point Basil sulks to Sybil 'If you think I'm going to fawn to those yobbos...', neatly summing up his attitude to the guests and therefore the communal well being of the hotel. For Basil's character it is not helping or promoting togetherness whilst under the same roof, it is fawning and a battle between him and the guests. This therefore suggests in return, that Basil sees the formation of his community, and therefore his nation, as a clash and a battle between different classes.

It has already been shown how much of Basil's personal ideology revolves around past conflicts and wars that Britain has been involved and how that period of history is the one that seemingly inflects how he posits the way the hotel should be run. It is also seen throughout the series that his language reflects this way of thinking too. When the hotel is threatened with closure from the health inspector, Basil's character attempts to rally the staff with a cry of, 'We didn't win the war by being depressed you know!'. For Basil then, the running of the hotel is a war, with the enemy being those that do fit into his strict criteria for entry. It is because of this then, that the community is continually bedevilled by conflict and crisis. For Basil the conflict comes because the social divisions that are so important for how Britain should be structured are clearly breaking down. Margaret Thatcher is a figure of jokes and fun, the automotive industry goes on strike regularly and working class people are free to come and go as they please within his hotel. It is for these reasons then, that Basil fights against the breaking social divisions within his community and tries to reassert the old, traditional order by stratifying and structuring his community around clear, class and ethnicity based guidelines. However, as argued previously, Basil's character is perhaps too blinded in his admiration of the old world order to realise that the character and make-up of society is changing inevitably and irrevocably, with the result being that his attempt at fostering a particular breed of class and character within his community is doomed to fail, linked to the idea that communities are best constructed around a coming together of different cultures as these differences in cultures are reduced towards reaching a common goal (Barth, 1970). Basil's character however, does not share a common goal with any character that does not fit into his own cultural and ethnic standpoint. Other textual studies of representations of communities may well show that they are founded upon an 'us opposed to them' ideology (Geraghty, 2000), but Basil's character has taken this to a manic extreme, to a point where there is no 'us' only 'him'.

The series ends in Basil the Rat with no real sense of closure or narrative climax. Instead it presumably resides on the point of disaster and closure because a rat is running free in the hotel in plain view of a health inspector. This is probably an appropriate end for the community, as Basil has not tried to change the way he has tried to run the community at all. Instead, he has let divisions and problems fester and exist without healing them, leading to a community that is on the permanent point of collapse because of Basil's strict nationalistic view on how people should behave, and who should be allowed into his little extension of England, despite the fact his belief is rooted in an England and a Britain that no longer exists.

\section{References}

Anderson, B. (1983) The Origins of National Consciousness. In: Boyd-Barrett, O., McKenna, J., Sreberny-Mohammadi, A. and Winseck, D., eds. Media in Global Context: A Reader. Bristol: Arnold, 1997

Barber, S. (2002) Projected Cities: Cinema and Urban Space. London: Cromwell Press. 
Barth, F. (1970) Introductory Essay In: Barth, F., ed. Ethnic Groups and Boundaries: The Social Organization of Culture Difference. London: George Allen and Unwin, 1997, pp 10.

Barthes, R. (1993) Mythologies. London: Vintage.

Bauman, Z. (2004) Community: Seeking Safety in an Insecure World. Oxford: Blackwell Publishing Ltd.

Bilig, M. (1995) Banal Nationalism. London: Sage Publications.

Billingham, P. (2003) Sensing the City through Television. Bristol: Intellect Books.

Chambers, C and Prior, M. (1987) Playwright's Progress: Postwar British Drama. Oxford: Amber Lane Press.

Cohen, A.P. (1985) The Symbolic Construction of Community. London: Routledge.

Delanty, G. (2005) Community. Oxon: Routledge.

Geraghty, C. (2000) The Construction of a Community. In: Buscombe, E., ed. British Television: A Reader. Oxford: Clarendon Press, 2000, pp 173-184.

Hartley, J. (1999) Uses of Television. London: Routledge.

Higson, A. (1998) Nationality: National Identity and the Media In: Briggs, A. and Cobley, P., eds. The Media: An Introduction. Essex: Longman, 1998

Hoggart, R. (2004) Mass Media in a Mass Society: Myth and Reality. London: Continuum.

Innes, C. (1992) Modern British Cinema 1890-1990. Cambridge: Cambridge University Press.

Jacobson, J. (1997) Perceptions of Britishness. London: Asen.

Lacey, N. (1998) Image and Representation - Key Concepts in Media Studies. Hampshire: Palgrave.

McCrone, D. (1996) The Sociology of Nationalism: Tomorrow's Ancestors. London: Routledge.

Nisbet, R.A. (1953) The Quest for Community. London: Open University Press.

Pettitt, L. (2000) Screening Ireland: Film and Television Representation. Manchester: Manchester University Press

Pickering, M. (2001) Stereotyping: The Politics of Representation. Hampshire: Palgrave.

Shiel, M. (2003) A Nostalgia for Modernity: New York, Los Angeles, and American Cinema in the 1970s In: Fitzmaurice, T. and Shiel, M., eds. Screening the City. London: Verso, 2003, pp 160-180. 
Smith, AD. (1991) National Identity. London: Penguin Books.

Thompson, JB. (1995) The Media and Modernity: A Social Theory of the Media. Cornwall: Polity Press.

Tueth, M.V. (2000) 'Fun City: TV's Urban Situation Comedies of the 1990s'. Journal of Popular Film and Television. 28(3):100-102.

Tyler, R. (2005) Comprehending Community. In: Herbrechter, S. and Higgins, M., eds. Returning (to) Community: Theory, Culture and Political Practice of the Communal. Amsterdam: Rodopi, 2005, pp 19-25

Wagg, S. (1998) At Ease, Corporal. Social class and situation comedy in British Television from the 1950s to the 1990s' In: Wagg, S., ed. Because I Tell a Joke or Two: Comedy, Politics and Social Difference. London: Routledge, 1998, pp 1-32. 